\title{
An examination of adolescents' attitudes towards leisure activities
}

\author{
Sabri Kaya ${ }^{1}$ \\ Emanuele Isidori ${ }^{2}$ \\ Halil Sarol $^{3}$
}

\begin{abstract}
The aim of this study was to examine the attitudes level towards leisure activities of adolescents and to compare the participants' attitudes levels according to some variables. $610\left(\mathrm{~N}_{\text {male }}=333\right.$; $\mathrm{M}_{\text {age }}=15.80, \mathrm{SD}=1.14$ and $\mathrm{N}_{\text {female }}=277 ; \mathrm{M}_{\text {age }}=15.66, \mathrm{SD}=1.01$ ) adolescents enrolled in this study from different high schools in Turkey. The Leisure Attitude Scale (LAS) (Ragheb and Beard, 1982) was administered on the participants. Cognitive, affective and behavioral items (12 per type) were rated on a five-point Likert scale. Descriptive statistical methods and MANOVA were used to compare the differential scores of the three sub-scales of the T-LAS among the demographic variables. Correlation analysis was used to test the relationship between T-LAS sub-scales and age. The cognitive sub-scale scores were the highest toward leisure. MANOVA analysis indicated no significant mean differences in all three sub-scales with regard to gender. However, there were no significant main effect of participation in physical activity on "T-LAS" scores; a follow-up univariate analysis indicated significant main effects for participation in physical activity on the sub-scales of "Cognitive", "Affective", "Behavioral". Participants groups had higher mean attitude scores than the non-participants in all sub-scales of T-LAS. Additionally, MANOVA indicated significant main effect of school type on "T-LAS" scores, in tests between subject effects by school type, results also revealed a significant differences in the "Cognitive", "Affective", "Behavioral" sub-scales. Private high schools' students had higher scores than the others. Overall, the girl participants had lower attitudes toward leisure than the boys. While the highest leisure attitudes mean score in affective sub-scale, cognitive subscale is the lowest score.
\end{abstract}

Keywords: Leisure, recreation, activities, attitude, adolescents

\section{Introduction}

In the culture of any society there is time for leisure as well as for the leisure activities (Kilbas, 1994). Although there is more leisure time today than ever has been in the history; it is a challenge to make the best of this time, especially for those who have it in abundance (Agate et al., 2009; Lu and Kao, 2009). Leisure Study Association (2015) states that "leisure is important to all of us. It is a

\footnotetext{
1 Assistant Professor, Kurrkkale University, Faculty of Sport Sciences, sabrikaya@kku.edu.tr

${ }^{2}$ Associate Professor, University of Rome "Foro Italico", Science of Education, emanuele.isidori@,uniroma4.it

${ }^{3}$ Expert, Ph.D., Gazi University, School of Physical Education, hsarol@gazi.edu.tr
} 
Kaya, S., Isidori, E., \& Sarol, H. (2015). An examination of adolescents' attitudes towards leisure activities. International Journal of Human Sciences, 12(2), 485-501. doi: 10.14687/ijhs.v12i2.3356

sphere of life in which individuals find enjoyment, fulfillment, friendship and well-being. Participation in leisure contributes both to personal health and the maintenance of social life". With the industrial revolution having taken place, the changes in the life of work made human life better planned, making the life out of work be better defined than before (Aslan, 2005).

Additionally, in developed countries and partially in developing countries also, as a result of civilization and development, individuals are in a strife to make better use of their spare time within the limits of given opportunities and personal means as a result of the improvement in perception of leisure and changes in the social norms. The social and societal value of leisure time in life is rising with a quick pace while also coming into focus (Languar, 1991). In this matter, adults are not the only ones with a growing concern to use leisure time to good account, the phenomenon has a prominent place in the lives of the adolescents also, and they, just like any individual in the society, are in need of leisure and to realize themselves via taking part in active or passive leisure activities.

Of all phases in a life span, adolescence is the phase leisure is an important part of scientific research as it is a time where individuals go through important changes and personal development in a quick pace (Learner and Overton, 2010). Hence, it has become one of the major concerns of scientists to have insight on how leisure become the part of individual's social life and the reasons behind the positive and negative attitudes the individuals develop towards leisure (Mannell and Kleiber, 1997).

Adolescence is a challenging period where individuals move from childhood on to the world of adults. It is essential in this process that individuals develop a strong and steady personality. While constructing their individuality and sense and perceptions of social belonging through various opportunity and experiences (Shaw et al., 1995), adolescents leave their childish attitudes and behaviors for more mature ones; and they also develop the sense of social acceptance and belonging to a group in the process of psychological preparation to play the role of an adult. In adolescence where the physical, social and psychological changes accelerate, spending time with friends, being part of a friend circle is preferred by the individuals. In this phase, relationships with peers become prominent and leisure activities gain importance developmentally for "through them new skills are developed, social relationships are established and new identities are formed" (Trainor et al., 2009:1). The leisure time issue is a phenomenon that commences in childhood and proceeds into adolescence, youth and adulthood with changes (Hoff and Ellis, 1992).

Adolescents usually go through this phase in school. This indeed puts forth the important role the school plays in leisure and leisure activities. Schools are places not only preparing adolescents to life but also teaching them life. Leisure is one of the indispensable elements of human life. In which activities the adolescents are skilled is detected in schools and their attitude 
Kaya, S., Isidori, E., \& Sarol, H. (2015). An examination of adolescents' attitudes towards leisure activities. International Journal of Human Sciences, 12(2), 485-501. doi: 10.14687/ijhs.v12i2.3356

and values are developed in these skills. The leisure activities are provided in the most satisfactory manner as possible. The schools are the most convenient places where adolescents fulfill their physical, psychological and social needs using the leisure time efficiently within the given limits.

Especially in developed western countries, the school is perceived as a center where not only students' needs for leisure activities are fulfilled but also the needs of whole society. These countries give a major place to the leisure activities and arts in their curriculum. Physical education, language, graphic arts, social analyses are taught in the classrooms in order to contribute to the personal leisure resources of the student. It is also seen that leisure subjects are given place in the syllabus of other courses. Again in these institutions informal leisure activity trainings are given. Active and passive games and sportive activities are held without the school hours as out of class activities. And within these programs applied and experimental activities such as flying, skiing, camping and diving are taught.

On the other hand, when a glance is cast to the curriculum of our country, it is not really possible to point to any emphasis separately and consciously given to leisure and using leisure. However; within the general roles of education, the school is given the responsibility to guide the child to make good use of leisure. Nevertheless as proper curriculum and proper content is not given, this purpose cannot be realized in practice.

Additionally, it can be observed that the educational branches created as an obligation of the curriculum are ineffective, insufficient and not applied out of school hours. Thus it is seen essential that effective leisure attitudes, approaches and related policies are formed in the education system. In the purposes of National Education of Turkey, there are principles such as "using leisure time effectively", and "developing appreciation of fine arts". However the means to apply these principles is not provided. To give an example, there are not any program leaders and trainers assigned to lead and train the individuals in the leisure activities out of the school hours. The school hours given to adolescents as leisure and to practice leisure activities are either limited or missing altogether.

Be it within or without school hours, there are many factors defining the participation in active or passive leisure activities or other types of activities. The most prominent of these factors is "attitude". In the research by İnceoğlu (1993), it was stated that everything in life depends on attitudes which are the known driving forces behind the actions. It can be claimed that attitudes are very important and definitive factors in adolescence also.

The positive attitudes a person develops in childhood and adolescence define the actions embedded in the life of an adult (Stanescu et al., 2014). It is crucial to introduce a child to physically active leisure activities in order to facilitate the development of related physical activity skills, 
Kaya, S., Isidori, E., \& Sarol, H. (2015). An examination of adolescents' attitudes towards leisure activities. International Journal of Human Sciences, 12(2), 485-501. doi: 10.14687/ijhs.v12i2.3356

attitudes, values and behaviors as there is no better time for an individual to acquire such skills than the childhood (Telama et al., 1997).

As a complementary to the opinion above, in a research by Dzewaltowski (1989) a positive relation was detected between attitude and intention to participate in leisure activities and selfefficacy. Researches also revealed that the attitude factor affects the participation in physical leisure activities (Iso-Ahola, 1980; Ajzen and Fishbein, 1980; Ragheb, 1980; Davis et al., 1984;. Ragheb and Tate, 1993; Watson, 1996).

Through this study, a more comprehensive understanding on the effects of leisure in the life of adolescents and their manner of participation in leisure experiences may be gathered. Leisure activities are efficient means of socialization and learning in adolescence with the unique skills they may help individuals obtain and develop. It has been the concern of many researchers to know more about how individuals become involved in leisure activities and through which processes they take on a positive or negative attitude towards leisure (Iso-Ahola and Weissinger, 1990; Ragheb and Tate, 1993; Stelzer et al., 2004; Warn, 1999; Watson, 1996; Deng et al., 2005; Sindik et al., 2009).

\section{Literature Review}

It is seen in the related literature that researchers conduct various studies in order to comprehend what sort of positive or negative factors affect individuals' attitude towards leisure and detect how and where from these factors emerge (Cunningham and Kwon, 2003; Trail et al., 2002; Henderson and Ainsworth, 2001; Chung and Philips, 2002; Edgington, 2007; Sandahl, 1992; Ragheb, 1980; Iso-Ahola and Weissinger, 1990; Ragheb and Tate, 1993; Stelzer et al., 2004; Warn, 1999; Watson, 1996; Deng et al., 2005; Sindik et al., 2009).

Defining the relationship between definitive concepts of our study, adolescence, attitude and leisure with support from the literature will assist a better understanding of the issue.

\section{Adolescence}

The phase called adolescence begins with the early years of puberty and ends between ages 19-20 and marks the passage from childhood to adulthood. Individuals go through significant amount of psychological changes and emotional developments while constructing their identity, establishing independence, acquiring and constructing their value system and also building intimate adult relationships in the process (Cordes and Ibrahim, 1996). Kelly (1983) states that adolescence is the time many identities an individual needs throughout the course of life are developed such as sexual, productive, social and intimate identities (Kelly, 1983) 
Kaya, S., Isidori, E., \& Sarol, H. (2015). An examination of adolescents' attitudes towards leisure activities. International Journal of Human Sciences, 12(2), 485-501. doi: 10.14687/ijhs.v12i2.3356

The phase of adolescence also marks the emergence of emotional maturity, a more intense interest in the opposite sex, social maturity in general, economical independence and a will to use the leisure time (Yavuzer, 2005). Especially the cognitive changes an adolescent goes through have effects reaching as far as individuals own psychological development and social relationships. Hence, adolescence is a critical phase for the development of more complex and advanced perceptions of life (Steinberg, 2007).

\section{Attitude}

There are many factors at work in participation in leisure activities or other kinds of activities. The most prominent of these factors is the concept of "attitude". In a study by Inceoğlu (1993) it is stated that everything in life depends on attitudes as the known driving forces behind actions.

Although there are many ways to define attitude, as claimed by researches over the course of many years, the prominent opinion remains to be that a negative or positive perception of a behavior constructs the attitude level of an individual (Ajzen, 1991) thus forming a positive or a negative judgment pattern of an idea or a behavior (Eagry and Chaiken, 1993). As a generalization, attitude is a phenomenon acquired through learning, and while guiding individual's behavior, it is also prone to cause bias in the decision making process (Erkuş 2003). According to Gardner (1985), attitude is the reaction of an individual towards a given object or concept based on their beliefs and ideas. While Papanastasiou (2002) defines attitude as: "attitude is an individual's positive or negative emotional disposition towards things, people, places, events or ideas", Sherif and Sherif (1996) defines attitude as a condition of being quite constantly ready to decide whether a positive or a negative response is to be given to a thing or a situation labeled by a moral judgment as a result of a psychological reasoning.

\section{Leisure attitude and adolescence}

Leisure attitude could be explained as a prepared stance of individuals towards their leisure time depending on their perception, belief, and positive or negative orientation. Attitudes are claimed to have affective, cognitive and behavioral aspects (Ragheb and Beard, 1982). Since positive attitudes towards leisure often mean greater participation in leisure, it is crucial to better understand the aspects of leisure (Texeria, 2013). In the case of young adults and adolescents, leisure emerges as an important developmental element in their life (Larson, 2000). In the development of young individuals, positive leisure experiences assist the formation of autonomy and self-efficacy (Stebbins, 1992). According to Wang (2001) participation in leisure in adolescence prepares the 
Kaya, S., Isidori, E., \& Sarol, H. (2015). An examination of adolescents' attitudes towards leisure activities. International Journal of Human Sciences, 12(2), 485-501. doi: 10.14687/ijhs.v12i2.3356

individuals for the adult life thus playing a major role in their development while also occupying a vast space in their life.

Participation in leisure activities can have many forms as "hanging out" with friends, reading or joining clubs or sports. "There is a general consensus that leisure-time and recreational activities are not only ends, providing immediate gratification and enjoyment, but also means for attaining long-range personal and social goals" (Willits and Willits, 1986: 190). Active participation in leisure activities plays in important role in healthy psychological development thus a closer look on these activities can be of great use to gather more information on adolescents in terms of both social and psychological aspects. One of the ways to utilize the knowledge is to assess how successfully the needs of the individuals are fulfilled through the provided activities and occupations (Garton and Pratt, 1991).

It has been stated in a research (Hultsman, 1993; Orthner et al., 1994) that individuals' beliefs about leisure are formed through their socialization by parents which is not so surprising a statement after all. Nevertheless, according to Iso-Ahola (1995) no matter how clear the process of acquiring a leisure attitude and its longitude may be in a sense, the area still lacks a satisfactory number of studies. The concept of leisure participation, as stated by Ragheb and Griffith (1982), is related to the frequency of attendance of an individual in a certain leisure activity. Leisure activities play a greater role in adolescence as they facilitate the formation of identity and experimentation of one's autonomy while serving the individual on their social endeavors (Gordon and Caltabiano, 1996). In addition to providing the opportunity to explore the roles played as peers, family and community, the leisure activities also assist adolescents in the improvement of their sociocultural knowledge, putting their social and cooperative skills in use and help them reach out to their intellectual and physical goals (Gordon and Caltabiano, 1996). The contentment with leisure comes from the leisure activity chosen by an individual (Beard and Ragheb, 1980) and it is measured by assessing to which degree an individual is provided with their needs consciously or unconsciously. Relief from stress, increasing leaning efficiency and mental and physical balance have become essential elements of life, expanding the role leisure plays in the life of an individual as the provider of these needs. According to Mannell et al., (1988) the higher leisure satisfaction is, the higher sense of life satisfaction also is.

It is important to point out to the correlation between attitude and constraints which states that a negative attitude towards leisure is prone to set limits on leisure (Mannell and Kleiber, 1997). In the study by Jackson (1990) it is stated that motivated individuals experience fewer constraints in their leisure participation while more reluctant ones state a higher sense of limitation. It is also reported by Jackson et al., that through negotiations of the constraints, leisure activity may become 
Kaya, S., Isidori, E., \& Sarol, H. (2015). An examination of adolescents' attitudes towards leisure activities. International Journal of Human Sciences, 12(2), 485-501. doi: 10.14687/ijhs.v12i2.3356

more satisfactory. The opinion is compatible with the claim that perceived control in the leisure setting affects the perceived leisure freedom (Ellis and Witt, 1994).

In the light of all of the above, it is obvious that attitude should be approached as a definitive factor in leisure tendencies as in all other areas.

As a contribution and support to this opinion, in the research by Dzewaltowski (1989) a positive relation was detected between intention of participation in leisure activities and attitude and self-efficacy. In the findings of the research by Ragheb, 1980; Crandall and Slivken, 1980; Watson, 1996 a relation between attitude and participation in physical activities was discovered. The research also points out that the factor of attitude affects the participation in physical leisure activities (IsoAhola, 1980; Ajzen \& Fishbein, 1980; Ragheb, 1980; Davis et al., 1984; Ragheb and Tate, 1993; Watson, 1996). Development of a positive attitude towards leisure is an important issue in Turkey, as it is one of the means for the adolescents to take leave from the dull nature of their life.

Within the light of all of these reasons combined, the goal of the study is to detect the attitude of the adolescents towards the leisure activities and compare these attitude levels in terms of some variables (gender, age, participation in physical activities and school type). A study which examines and compares the leisure attitude of adolescents who study in state schools, private high schools and theology schools is not encountered in the literature. In this regard, our study is the first in its area to contribute to the literature.

\section{Methods}

610 adolescence $\left(\mathrm{N}_{\text {male }}=333 ; \mathrm{M}_{\text {age }}=15.80\right.$ yr., $\mathrm{SD}=1.14$ and $\mathrm{N}_{\text {female }}=277 ; \mathrm{M}_{\text {age }}=15.66 \mathrm{yr}$., $\mathrm{SD}=1.01)$ students enrolled voluntarily in this study from different big high schools in Middle Anatolia region in Turkey.

\section{Measures}

Students' attitudes were described using three structured scales. In the questionnaire were demographic data, leisure involvement and the leisure attitude scale and an overall response rate of \% 87.1 (610 of 700). Developed mainly based on Leisure Motivation Scale (Beard and Ragheb 1982) and the literature in the field, the Leisure Attitude Scale (LAS) was used in the study. The Scale was used to measure the attitudes of the adolescents. The Leisure Attitude Scale was adapted to Turkish by Akgül and Gürbüz (2010) (T-LAS). Cronbach Alpha internal consistency coefficient was calculated to test the reliability of the scale. The reliability score of the scale was 93. Alpha reliabilities for the Cognitive, Affective, and Behavioral sub-scales were .93, .91, and .91, respectively. Made up of 36 items in total, The Leisure Attitude Scale (LAS) also examines certain 
Kaya, S., Isidori, E., \& Sarol, H. (2015). An examination of adolescents' attitudes towards leisure activities. International Journal of Human Sciences, 12(2), 485-501. doi: 10.14687/ijhs.v12i2.3356

aspects of attitude via three sub-scales. 12 items about knowledge on leisure and beliefs about its value make up the cognitive sub-scale. There are 12 items about feelings towards leisure activities such as liking and disliking in the affective sub-scale. In the Behavioral sub-scale there are 12 items about past, present and intended actions related to leisure activities and experiences (Ragheb and Beard, 1982). Five-point Likert scale was used to rate the cognitive, affective and behavioral items (12 items per type). With regards to Likert scale, it was asked of the participants to rate every item from 1 = strongly disagree to $5=$ strongly agree.

\section{Data Analysis}

A statistical package of SPSS Version 15.0 was used to analyze the questionnaires collected from the participants. In order to compare the differential scores of the three sub-scales of the TLAS among the demographic valuables, MANOVA and descriptive statistical methods were used. And the relationship between T-LAS sub-scales and age were detected by correlation analysis.

\section{Findings}

The goal of the study is to detect the attitudes of the adolescents towards leisure activities and compare the attitude levels according to some variables (gender, age, participation in physical activities and school type). According to the results of the analysis; when the participants' mean scores related to the factors constructing the sub-scales of "Leisure Activity Scale" were examined, it was discovered that the highest scores were in the Affective $(M=3.72)$ sub-scale followed by behavioral ( $\mathrm{M}=3.55)$ sub-scale and Cognitive $(\mathrm{M}=3.37$ ) sub-scale respectively (Table 1). Regarding these scores, one may read that adolescents enjoy participating in leisure activities, yet they do not convert it to a sustainable behavior.

Table 1. The average values and standard deviation values of the LAS sub-scales scores of the participants.

\begin{tabular}{|c|c|c|c|}
\hline Sub-scales & $\mathbf{N}$ & $\mathbf{M}$ & SD \\
\hline Cognitive & 605 & 3.37 & 0.89 \\
\hline Affective & 606 & 3.72 & 0.88 \\
\hline Behavioral & 608 & 3.55 & 0.90 \\
\hline
\end{tabular}

When we looked at the LAS sub-scale scores of the participants in terms of gender; there were no indications of significant mean differences $(p>0.05)$ in any of the sub-scales in terms of gender. However, there were no significant main effect of participation in physical activity on "T- 
Kaya, S., Isidori, E., \& Sarol, H. (2015). An examination of adolescents' attitudes towards leisure activities. International Journal of Human Sciences, 12(2), 485-501. doi: $\underline{10.14687 / \mathrm{ijhs.v12i2.3356}}$

LAS” scores $[\lambda=0.989, \mathrm{~F}(3,596)=2.155, \mathrm{p}<0.01]$. The LAS sub-scale scores of men were detected to be higher than the women although not within significant levels (Table 2).

Table 2. The MANOVA Results of LAS Sub-Scale Scores of Participants with Regard to Their Gender.

\begin{tabular}{|c|c|c|c|c|}
\hline \multirow{2}{*}{ Sub-scales } & \multicolumn{2}{|c|}{ Female $(N=273)$} & \multicolumn{2}{|c|}{ Male $(\mathrm{N}=327)$} \\
\hline & $M$ & $S D$ & $M$ & $S D$ \\
\hline Cognitive & 3.34 & .91 & 3.39 & .87 \\
\hline Affective & 3.72 & .88 & 3.74 & .88 \\
\hline Behavioral & 3.53 & .91 & 3.57 & .90 \\
\hline
\end{tabular}

However, participation in physical activity did not indicate a significant main effect in LAS" scores $[\lambda=0.989, \mathrm{~F}(3,596)=2.155, \mathrm{p}<0.01]$. A follow-up univariate analysis indicated significant main effects for participation in physical activity on the sub-scales of "Cognitive" $[F(1,598)=5.790$, $\mathrm{p}<0.05]$, "Affective" $[\mathrm{F}(1,598)=5.609, \mathrm{p}<0.05]$, "Behavioral” $[\mathrm{F}(1,598)=5.097, \mathrm{p}<0.05]$. All subscales of T-LAS being considered, the groups who participated did have higher mean attitude scores that those of the non-participants. These scores can be read as; adolescents are fond of participating in leisure activities or the idea of participating: however they find in difficult to maintain and practice it as a habit. (Table 3)

Table 3. The T-Test Scores of LAS Sub-Scales Regarding Participation in Physical Activities

\begin{tabular}{|c|c|c|c|c|}
\hline Sub-Scales & Participation PA & $M$ & $S D$ & $N$ \\
\hline \multirow{2}{*}{ Cognitive } & Yes & 3.43 & .88 & 401 \\
\hline & No & 3.24 & .89 & 199 \\
\hline \multirow{2}{*}{ Affective } & Yes & 3.79 & .89 & 401 \\
\hline & No & 3.61 & .83 & 199 \\
\hline \multirow{2}{*}{ Behavioral } & Yes & 3.61 & .90 & 401 \\
\hline & No & 3.43 & .91 & 199 \\
\hline
\end{tabular}

According to MANOVA school type also significantly affected the T-LAS scores $[\lambda=0.918$, $\mathrm{F}(3,596)=2.334, \mathrm{p}<0.05]$, when the effects of subjects with regard to school type were analyzed, significant differences in "Cognitive" $[\mathrm{F}(2,597)=6.194, \mathrm{p}<0.05]$, "Affective" $[\mathrm{F}(2,597)=5.264$, $\mathrm{p}<0.05]$, "Behavioral" $[\mathrm{F}(2,597)=4.371, \mathrm{p}<0.05]$ sub-scales were revealed. Accordingly, while private high school students scored higher than the others, the adolescents who are theology high school students had the lowest scores (Table 4). 
Kaya, S., Isidori, E., \& Sarol, H. (2015). An examination of adolescents' attitudes towards leisure activities. International Journal of Human Sciences, 12(2), 485-501. doi: 10.14687/ijhs.v12i2.3356

Table 4. ANOVA and MANOVA Results by School Type

\begin{tabular}{|c|c|c|c|c|c|c|}
\hline \multirow[t]{2}{*}{ Sub-Scales } & \multicolumn{2}{|c|}{$\begin{array}{l}\text { Private High School } \\
(\mathrm{N}=164)\end{array}$} & \multicolumn{2}{|c|}{$\begin{array}{l}\text { State High School } \\
(\mathrm{N}=139)\end{array}$} & \multicolumn{2}{|c|}{$\begin{array}{l}\text { Theology High } \\
\text { School } \\
(\mathrm{N}=297)\end{array}$} \\
\hline & $M$ & $S D$ & $M$ & $S D$ & $M$ & $S D$ \\
\hline Cognitive & 3.55 & 1.87 & 3.41 & .91 & 3.25 & 1.87 \\
\hline Affective & 3.91 & .90 & 3.73 & 0.88 & 3.63 & 0.85 \\
\hline Behavioral & 3.71 & .85 & 3.58 & .95 & 3.45 & .90 \\
\hline
\end{tabular}

The test results did not indicate significant correlations between three sub-scales of LAS and age ( $\mathrm{p}$ $>0.05)$. (Table 5).

Table 5. Correlation between Age and Leisure Attitudes

$\left.\begin{array}{|l|l|l|l|l|}\hline \text { Sub-scales } & \text { Age } & \text { Cognitive } & \text { Affective } & \text { Behavioral } \\ \hline \text { Age } & 1 & & & \\ \hline \text { Cognitive } & -, 069 & 1 & & \\ \hline \text { Affective } & -, 075 & 0.845^{* *} & 1 & \\ \hline \text { Behavioral } & -, 066 & 0.704^{* *} & 0.789 *\end{array}\right]$

\section{Discussion and Conclusion}

According to the findings of the study conducted to assess the attitudes of adolescents towards the leisure activities, the scores of the participants rank as "affective", "behavioral" and "cognitive" respectively. This result is in parallelism with the results of the study in the literature by Teixeria and Freire (2013). However, it is also gathered that the attitude scores of the participants are mainly on the affective level and are not reflected as much in the behaviors.

That the participation in the physical activities in adolescence is higher may indicate the effort of the adolescents to better understand the world and their body as a result of their physical development and the dominating development of conceptual thinking. Adolescents' sparing more time for social activities and less for physical and intellectual activities are in similarity to the findings of the study by Larson and Seepersad (2003).

The analysis showed that age and gender variables did not have the expected effect on the attitude scores of the adolescents. Nonetheless, according to the gender variables, the attitude scores of male adolescents are relatively higher than the female adolescents in all the sub-scales. From these statistics it can be inferred that the female adolescents do not have the opportunity and freedom to participate in the leisure activities as much as the male adolescents because of the roles tailored and imposed on women and the relative social pressure cast on them as a consequence of 
Kaya, S., Isidori, E., \& Sarol, H. (2015). An examination of adolescents' attitudes towards leisure activities. International Journal of Human Sciences, 12(2), 485-501. doi: 10.14687/ijhs.v12i2.3356

living in a Muslim community. This inference has similarities with the study by Sarol et al., (2012). Moreover, the average scores of attitude in terms of both gender and age categories were found to be quite similar. The close averages are considered to result from the slight age differences between the adolescents.

According to another result gathered from the study, the scores of the individuals who participate in physical activities in their leisure are higher than those of non-participants as expected. These results can be read as the presence of a significant relationship between attitude towards participation in leisure activities and participation in physical activities. It is compatible with the previous studies on adolescents and young individuals that while boys test their developing bodies via physical activities, girls focus on their bodies trying to adapt to their changing physical natures in the adolescence where great physical changes take place (Tezcan, 1982; Larson and Seepersad, 2003; Aslan, 2005; Kerner, 2005).

Similarly, as to provide support to the results of the study, the relationships between leisure, participation in activities, satisfaction and attitude towards participation in activities investigated and found by Ragheb (1980), Feltz (1982, 1988), McAuley and Courneya (1993) correspond to the ones in this study. Moreover, positive relationships were reported by Dzewaltowski (1989) between intention to exercise and the exercise behavior, attitude and self-efficacy when exercise behavior is concerned. Therefore it can be said that a relationship between attitude and participation in physical activity was found in previous studies in the field (Crandall \& Slivken, 1980; Watson, 1996; Chih Mou Hsieh, 1998; Iso-Ahola and Weissinger (1990); Hagger et al. (2001); Dzewaltowski et al. (1990))

Although the findings about relationships by Ragheb (1980), Feltz (1988, 1992), and McAuley $(1992,1993)$ and this study are in parallelism, in spite of the positive correlation between attitude and physical activity participation, it was stated by Crandall and Slivken (1980) that there is a weak interrelation between attitude and behavior as there also may be constraints or competition that deter and discourage the individual from realizing the attitude. On the other hand, it was claimed by Fishbein and Ajzen (1975) that attitudes do not precisely foretell a certain action for they have a general nature.

The relationships between leisure participation, contentment and attitude were also researched by Ragheb (1980). According to the report by Kaufman (1988) there is a significant positive relationship between leisure participation and leisure satisfaction. Additionally, negative relationships were found between boredom and leisure participation, motivation, attitude and satisfaction by Iso-Ahola and Weissinger (1990). 
Kaya, S., Isidori, E., \& Sarol, H. (2015). An examination of adolescents' attitudes towards leisure activities. International Journal of Human Sciences, 12(2), 485-501. doi: 10.14687/ijhs.v12i2.3356

The study also offers insight on the factors related to college students' participation in physical activities in their leisure time, its findings could be of great help for researchers, health educators and campus recreational professionals who are willing to work in the field of physical activities in leisure time and the attitudes of adolescents towards these activities. Moreover, in the light of the results taken from this study, it may be easier for the practitioners and professionals to recreate strategies of marketing or education in order to direct students to a pursuit of leisure time activity behavior that has previously been projected for them. Developing and implementing strategies intended to escalate the participation in leisure time activities could be better guided and assisted by the appropriate perception of the attitudes of adolescents towards their leisure time.

In the light of the results of the study, following suggestions can be offered to school administrations, families and recreational program developers and operators in terms of leisure attitudes of adolescents and making better use of leisure:

a) Increasing the value of the individual and cooperating with and assisting the individual in achieving happiness in life as schools are the main institutions responsible for teaching the individuals to use their leisure time in the best and most productive way. It must always be remembered that schools do not only educate adolescents to earn a living but also prepare them to life itself.

b) Adolescents should be motivated and encouraged in leisure activities while also developing related necessary attitude and values.

c) Especially the lack of attitudes of the adolescents toward leisure and leisure activities in state high schools and theology high Schools should be analyzed in dept. especially the low levels of attitudes and participation tendencies of the adolescents especially in theology high schools are a matter of concern. Therefore, the curriculum of the theology high schools should be reevaluated and the necessary regulations and program developments should be implemented.

d) Teaching leisure skills: School is ideally the best place to obtain the skills needed to use in the leisure and skills that give satisfaction to individuals. Some of these skills such as active and passive games, activities and various sports and dances and individual or group sports such as athletics, archery and football, basketball, handball, volleyball respectively help the physical development, being active and coordination. Some of the skills provided by schools may contribute to the safety and surviving skills of the individual adding to the pleasure taken out of life. The examples for these skills may be driving, knowledge of traffic rules and swimming. Some of the activities may contribute to the creative use of handicrafts such as painting, sculpting, carpentry, or other handicrafts. And some skills help with the communicational skills of the adolescents such as theatre, music, reading and writing. 
Kaya, S., Isidori, E., \& Sarol, H. (2015). An examination of adolescents' attitudes towards leisure activities. International Journal of Human Sciences, 12(2), 485-501. doi: 10.14687/ijhs.v12i2.3356

e) Development and improvement of leisure facilities and places and bestowing them to the use of the adolescents.

f) The physical resources should be developed for the use of the adolescents for leisure activities.

g) The educational branch activities in schools should be rendered more effective. As a suggestion these activities may be carried out of schools thus making it possible to multiply the duration of leisure activity participation and the number of individuals taking the opportunity.

h) Collaborations with other institution should be established in order to develop and increase the variation of the resources.

It is also essential to mention the constraints of the study as it was limited to high school students from certain state and private high schools in the Central Anatolia Region only. This limited sample may restrain making generalizations about the population in general or high school students from other environments.

It may be stated that the participants of the study group being selected from a limited source is the prime limitation of the study. Hence, in order to achieve an inclusive perspective on the attitudes of adolescents of Turkey towards leisure activities, studies should be conducted with larger samples inclusive of all Turkey. It is essential to include individuals with various demographical backgrounds in the researches to be made in the future to be able to generalize the findings for Turkey in general. Moreover a study comparing the leisure attitudes of the adolescents in Turkey with the adolescent in other countries in the world would contribute to the significance of the issue. Also, it may be suggested that, in order to analyze the main cause for the difference of attitudes of the adolescents in depth, the quantitative studies should be supported with qualitative studies.

\section{References}

Agate, J. R., Zabriskie, R. B., Agate, S. T., \& Poff, R. (2009). Family leisure satisfaction and satisfaction with family life. Journal of Leisure Research, 41(2), 205-223.

Ajzen, I. \& Fishbein, M. (1980). Understanding the Attitudes and Predicting Social Behavior. Englewood Cliffs, New Jersey: Prentice-Hall.

Ajzen, I. (1991). The theory of planned behavior. Organizational Behavior and Human Decision Processes, 50(2), 179-211.

Akgül, B.M. \& Gürbüz, B. (2010). Leisure Attitude Scale: The Study of Reliability and Validity. 11th International Sports Sciences Congress, 55, 10-12 November, Antalya, Turkey.

Anderson, N. (1998). Work and Leisure, Florence, KY: Routledge.

Aslan, N. (2005). Üniversite Öğrencilerinin Boș Zaman Değerlendirme Eğilimi: Öğretmen Yetiştiren Kurumlarda Karşılasturmalı Bir Araştırma. (2. Baskı). İzmir: Ege üniversitesi Basımevi.

Can, S., Durukan, E., Ökmen, A.Ş., Dalaman, O. \& Yorulmaz, A. (2012). İlköğretim Bölümü Öğretmen Adaylarının Serbest Zaman Faaliyetlerine Katılım Biçimlerinin Belirlenmesi. Selcuk Üniversitesi Beden Eğitimi ve Spor Bilimi Dergisi, 14 (1): 132-137. 
Kaya, S., Isidori, E., \& Sarol, H. (2015). An examination of adolescents' attitudes towards leisure activities. International Journal of Human Sciences, 12(2), 485-501. doi: 10.14687/ijhs.v12i2.3356

Cheng, S. T. (1995). The management of physical fitness program on campus. Paper presented in the 1997 NIKE Summer Fitness Workshop, Taipei: National Taiwan Normal University.

Cheng, S.T. (1998). A study on recreational sport participation model of university students in Taiwan. Taipei: National Science Council.

Chih-Mou Hsieh. (1998). Leisure attitudes, motivation, participation, and satisfaction: Test on a model of leisure behaviour. PhD diss., Indiana University.

Chung, M.H. \& Philips, D.A. (2002). The Relationship between Attitude toward Physical Education and Leisure Time Exercise in High School Students. Physical Educator, 59 (3):126138.

Cordes KA, Ibrahim HM (1996). Applications in Recreation and Leisure: For Today and the Future. St Louis, MO: Mosby.

Crandall, R. (1980). Motivation for leisure. Journal of Leisure Research, 12 (1): 45-54.

Crandall, R. \& Slivken, K. (1980). Leisure attitudes and their measurement. In S.E Iso-Ahola (Ed.), Social Psychology Perspectives On Leisure And Recreation: 261-248. Springfield, IL: Charles Thomas Publishers.

Cunningham, G. B. \& Kwon, H. (2003). The theory of planned behavior and intentions to attend a sport event. Sport Management Review, 6: 127-145.

Davis, K.E., Jackson, K.L., Kronenfeld, J.J. \& Blair, S.N. (1984). Intent to participation in work site health promotion activities: A model of risk factors and psycholosocial variables. Health Education Quarterly 11: 361-377.

Davison, K. K., \& Lawson, C. T. (2006). Do attributes in the physical environment influence children's physical activity? A review of the literature. International Journal of Behavioral Nutrition and Physical Activity, 3(19).

Deng, J., Walker, G., \& Swinnerton, G. (2005). Leisure Attitudes: A Comparison between Chinese in Canada and Anglo-Canadians. Leisure/Loisir, 29 (2): 239-273.

Drakou, A., Tzetzis, G., \& Mamantzi, K. (2008). Leisure constraints experienced by university students in Greece. The Sport Journal 11(1). http://www.thesportjournal.org/article [18 April 2009]

Driver, B., Brown, P. J., \& Peterson, G. (1991). Benefits of leisure (Ed.). State College, PA: Venture Publishing.

Dzewaltowski, D.A. (1989). Towards a model of exercise motivation. Journal of Sport and Exercise Psychology, 11: 251-269.

Dzewaltowski, D. A., Noble, J. M. and Shaw, J. M. (1990). Physical activity participation: Social cognitive theory versus the theories of reasoned action and planned behavior. Journal of Sport and Exercise Psychology, 12: 388-405.

Eagry, A. H., \& Chailen, S. (1993). Psychology of attitudes. Fort Worth, TX: Harcourt Brace Jovanovich.

Edginton, C. R. (2007). The world leisure organization: promoting social, cultural and economic transformation. Licere, Belo Horizonte, 10.

Erkuş, A. (2003). Psikometri Üzerine Yazılar, Türk Psikologlar Dernegi Yayınlar, 24, Ankara. 
Kaya, S., Isidori, E., \& Sarol, H. (2015). An examination of adolescents' attitudes towards leisure activities. International Journal of Human Sciences, 12(2), 485-501. doi: 10.14687/ijhs.v12i2.3356

Feltz, D. L. (1982). Path analysis of the causal elements of Bandura's theory of selfefficacy and an anxiety-based model of avoidance behaviour. Journal of Personality and Social Psychology, 42: 764-781.

Feltz, D. L. (1988). Self-confidence and sports performance. In K. B. Pandolf (ed.). Exercise and sports science reviews. New York: Academic Press, 75-109.

Feltz, D.L. (1992). Understanding motivation in sport: A self-efficacy perspective. In G.C. Roberts (Ed.), Motivation in Sport and Exercise: 93-106. Champaign, Illinois: Human Kinetics.

Fishbein, M., \& Ajzen, I. 1975. Belief, Attitude, Intention, And Behaviour: An Introduction To Theory And Research. Reading, MA: Addison-Wesley.

Gardner, R. C. (1985). Social Psychology and Social Language Learning: The Role of Motivation and Attitudes. Edward Arnold Inc., London.

Hagger, M. S., Chatzisarantis, N. and Biddle, S. J. H. (2001). The influence of self-efficacy and past behaviour on the physical activity intentions of young people. Journal of Sport Science, 19, 711-725.

Henderson, K. A., \& Ainsworth, B. (2001). Researching leisure and physical activity with women of color: Issues and emerging questions. Leisure Sciences, 23: 21.

Hoff, A.E. \& Ellis, G.D. (1992). Influence of agents of leisure socialization on leisure self-efficacy of university students. Journal of Leisure Research, 24(2), 114-126.

Iso-Ahola, S. E. (1980). The Social Psychology of Leisure and Recreation. Dubuque, IA: WC. C. Brown.

Iso-Ahola, S.E., \& Weissinger, E. (1990). Perceptions of boredom in leisure: conceptualization, reliability, and validity of the leisure boredom scale. Journal of Leisure Research, 22: 1-17.

İnceoglu, M. (1993). Tutum alg1 iletişim. Ankara: V Yayınları.

Kelly, J.R. (1983). Leisure Identities and Interactions. London: George Allen \& Unwin.

Kerner, M.S. (2005). Leisure-Time Physical Activity, Sedentary Behavior and Physical Fitness Among Adolescents. Journal of Physical Education, Recreation and Dance, 76(8), 26-35.

Kilbas, S. (1994). Gençlik ve Boș Zaman Değerlendirme (Youth and Leisure). Adana: Cukurova Universitesi Basimevi.

Laftman, S.B. \& Östberg, V. (2006). The Pros and Cons of Social Relations: An analysisof Adolescents' Health Complaints. Social Science \& Medicine, 63, 611-623.

Languar, R. (1991). Turizm-Seyahat Sosyolojisi, İstanbul: İletişim Yayınları.

Larson, R. \& Seepersad, S. (2003). Adolescents' Leisure Time in The United States: Partying, Sports, And The American Experiment. New Directionss For Child and Adolescent Development, 99, 53-64.

Learner, R. M. \& Overton,W. F. (Eds.). (2010). The handbook of life-span development. Hoboken, NJ: Wiley.

Lu, L., \& Kao, S. F. (2009). Direct and indirect effects of personality traits on leisure satisfaction: Evidence from a national probability sample in Taiwan. Social Behavior and Personality, 37(2), 191-192.

LSA (The Leisure Studies Association). Homepage. http://www.leisurestudies.org. Web. Jun 11, 2015.

Mannell, R.C., \& Kleiber, D.A. (1997). A social psychology of leisure. State College, PA: Venture. 
Kaya, S., Isidori, E., \& Sarol, H. (2015). An examination of adolescents' attitudes towards leisure activities. International Journal of Human Sciences, 12(2), 485-501. doi: 10.14687/ijhs.v12i2.3356

Menec, V. (2003). The relationship between everyday activities and successful aging: A 6-year longitudinal study. Journal of Gerontology: Social Sciences, 58B (2): S74-S82.

McAuley, E. 1992. The role of efficacy cognitions in the prediction of exercise of behaviour in middle-aged adults. Journal of Behaviour Medicine, 15: 65-88.

McAuley, E. \& Courneya, K.S. (1993). Adherence to exercise and physical activity as healthpromoting behaviours: Attitudinal and self-efficacy influences. Applied and Preventive Psychology, 2: 65-77.

Menec, V. (2003). The relationship between everyday activities and successful aging: A 6-year longitudinal study. Journal of Gerontology: Social Sciences, 58(2):74-S82.

Morgan, K. \& Bath, P. A. (1998). Customary physical activity and psychological wellbeing: A longitudinal study. Age and Aging, 27: 35-40.

Ozsaker, M. (2012). Gençlerin Serbest Zaman Aktivitelerine Katılamama Nedenleri Üzerine Bir İnceleme. Selçk Üniversitesi Beden Ë̆itimi ve Spor Bilimi Dergisi, 14 (1): 126-131.

Papanastasiou, C. (2002). School, teaching and family influence on student attitudes toward science: based on TIMSS data for Cyprus. Studies in Educational Evaluation, 28: 71-86.

Ragheb, M.G., \& Tate, R.L. (1993). A behaviour model of leisure participation based on leisure attitude, motivation and satisfaction. Leisure Studies, 12: 61-71.

Ragheb, M.G., Beard, J.G. (1982). Measuring leisure attitude. Journal of Leisure Research, 14(2): 155167.

Rokeach M. (1975). Beliefs Attitudes and Values. US A: Jossey-Bass Publishers.

Ruuskanen, J. M., Ruopilla, I. (1995). Physical activity and psychological well-being among people aged 65 to 84 years. Age and Ageing 24: 292-296.

Shaw, S.M., Kleiber D.A., Callwell, L.L. (1995). Leisure and identity formation in male and female adolescents: a preliminary examination. Journal of Leisure Research, 27 (3), 245-263.

Sarol, H., Gürbüz, B. \& Çimen, Z. (2012). “An Examination of Attitudes toward the Leisure Activities: A Sample of Adults" 12th International Sports Sciences Congress, 1870-1873, 12-14 December, Denizli, Turkey.

Sandahl, D. M. (1992). Leisure in Our Lives: Exploring The Common Leisure Occasion. Journal of Leisure Research, 24(1), 19-32.

Sherif, M., Sherif, C.W. (1996). Sosyal psikolojzye giriş II (Çev: M. Atakay ve A. Yılmaz). İstanbul: Sosyal Yayınlar.

Sindik, J., Andrijasevic, M., \& Curkovic, S. (2009). Relation of Student Attitude Toward Leisure Time Activities and Their Preferences Toward Sport Recreation Activities. Acta Kinesiologica, 3 (1) : 54-58.

Smith, M. B. (1968). Attitude Change. International Encyclopedia of The Social Sciences. Crowell and Mac Millan.

Steinberg, L. (2007). Ergenlik (You and Your Adolescent. İmge Kitapevi, Ankara.

Stanescu, M., Vasilea, L., \& Saftab, I. (2014). Educational Approaches Designed to Improve Active Lifestyle in Teenagers. Procedia - Social and Behavioral Sciences, 117, 27 - 33.

Stelzer J., Ernest J., Fenster M.J. \& Langford, G. (2004). Attitudes Toward Physical Education: A Study of Highschool Students From Four Countries- Austria, Czechrepublic, England and USA. College Student Journal, 38 (2): 171-178. 
Kaya, S., Isidori, E., \& Sarol, H. (2015). An examination of adolescents' attitudes towards leisure activities. International Journal of Human Sciences, 12(2), 485-501. doi: 10.14687/ijhs.v12i2.3356

Teixeria, A. \& Freire, T. (2013). The leisure attitude scale: Psychometric properties of a short version for adolescents and young adults. Leisure/Loisir, (37), 57-67

Telama, R. Yang, X., Laakso, L. \& Viikari, J. (1997). Physical activity in childhood and adolescence as predictors of physical activity in young adulthood. American Journal of Preventative Medicine, 13, 317-323.

Tezcan, M. (1982). Sosyolojïk açıdan boș zamanlarn değerlendirilmesi. Ankara: Ankara Üniversitesi Eğitim Bilimleri Fakültesi Yayınları.

Torkildsen G. (2005). Recreation and leisure management. 5th Ed. London and New York: Routledge, Taylor and Francis Group.

Trail, G. T., Anderson, D. F. \& Fink, J. S. (2002). Examination of gender differences in importance of and satisfaction with venue factors at intercollegiate basketball games. International Sports Journal, 6(1), 51-64

Trainor, S., Delfabbro, P., Anderson, S. \& Winefield, A. (2009). Leisure Activities and Adolescent Psychological Well Being. Journal of Adolescence, 3(03), 8-13.

Warn, S. (1999). Recreation and Tourism. Stanley Thornes (Publishers) Ltd.

Watson, J. F. (1996). The impact of leisure attitude and motivation on the physical recreation/leisure participation of college students. PhD. Dissertation, Purdue University.

Yavuzer, H., (2005). Gençleri Anlamak Ana-Babalarn En Çok Sorduğu Sorular ve Cevaplar. Remzi Kitapevi, İstanbul. 